\section{PEMBUATAN KONTEN \\ PEMBELAJARAN YANG \\ MENARIK BERBASIS \\ PEMECAHAN MASALAH DI SMP BP-ALMUNAWAROH}

Dian Mayasari', Sadrack Luden Pagiling ${ }^{2}$

1,2) Universitas Musamus

*Dian Mayasari

Email: mayasarifkip@unmus.ac.id

\section{Abstract}

Creating engaging content is the foundation for teachers to improve the quality of their students' learning. The training is designed to assist teachers in creating engaging learning experiences for their students and increasing student motivation to learn. Because of the current COVID-19 pandemic, all levels of education require distance learning. As a result, all teachers must deliver lessons to students remotely. Furthermore, this training is intended to prepare teachers to adapt to technological advancements because learning and teaching activities may be carried out online or offline in the future.

Keywords: Content; Learning; Problem Solving

\begin{abstract}
Abstrak
Pembutan Konten yang menarik menjadi dasar bagi guru untuk mningkatkam kualitas pembelajaran. Pelatihan dilakukan untuk memberikan pengarahan kepada guru dalam merancang pembelajaran yang menarik dan dapat meningkatkan motivasi siswa dalam belajar. Pandemi COVID- 19 yang terjadi saat ini menjadikan semua jenjang pendidikan untuk melakukan pembelajaran jarak jauh. Dengan demikian seluruh pengajar pun harus mampu memberikan pelajaran kepada siswa dengan jarak jauh. Disamping itu, pelatihan ini juga untuk mempersiapkan para pengajar untuk bisa terus beradaptasi dengan perkembangan teknologi. Karena tidak menutup kemungkinan bahwa di masa depan kegiatan belajar dan mengajar akan dilaksanakan secara daring ataupun luring.
\end{abstract}

Kata Kunci: Konten; Pembelajaran; Pemecahan Masalah 
Pembuatan Konten Pembelajaran yang Menarik Berbasis Pemecahan Masalah di Smp bp-almunawaroh

Dian Mayasari, Sadrack Luden Pagiling

Volume 1, No. 3, Desember 2021 hal. 247-252

DOI Artikel: 10.46306/jub.v1i3.47

PENDAHULUAN

Akhir tahun 2019, Indonesia dikejutkan dengan masuknya virus yang penyebarannya sangat cepat. Virus ini disebut dengan Corona Virus Diseases (Covid-19) yang dapat menyebar melalui droplet yang keluar dari si-penderita dan setelah menempel ke orang lain maka virusnya akan berkembang di tubuh yang baru. Salah satu cara yang dilakukan untuk memutuskan mata rantai virus corona ialah dengan tidak melakukan interaksi. Work frome home (WFH) ialah salah satu solusi dari pemerintah untuk mengurangi interaksi manusia. Dunia pendidikan melalui Mentri Pendidikan dan Kebuadayaan dengan Surat Edaran Nomor 36603/A.A5/OT/2020 tentang aktivitas belajar mengajar yang dilakukan di dalam kelas diganti dengan di rumah. Hal tersebut juga berdampak ke Merauke dimana pembelajarannya di lakukan di rumah.

Berdasarkan hasil wawancara dengan guru, bahwa proses pembajarannya yang dilakukan secara online ialah dengan memberikan materi dan tugas berupa pdf kedalam grup whatsapp. Hal tersebut terjadi karena ketidakpahaman guru dalam pengguanaan LMS dan penerapannya. Selain itu kebiasaan guru yang hanya di dalam kelas menjelaskan materi dan tiba-tiba harus melalukan pembelajaran online sehingga mereka bingung dalam pembuatan konten yang dapat menarik minat siswa untuk belajar. LMS yang telah diterapkan kepada guru selama masa pandemi ialah google classroom, edmodo, schoology dan Moodle (Batubara, 2004). Google classroom ialah aplikasi yang dibuat oleh google untuk membantu guru dan siswa untuk berkomunikasi secara daring (Soni et al., 2018; Munawaroh et al., 2021). Moodle merupakan sistem yang didesain untuk menampilkan, melacak dan mengatur konten pembelajaran dan interaksi siswa(Rizal \& Walidain, 2019). Edmodo merupakan platform pembelajaran yang berbasis media sosial (Pratama \& Ismiyanti, 2019;Nugraha \& Handayani, 202I). Schoology merupakan salah satu dari beberapa E-learning yan memberikan fasilitas kepada guru dan sisa untuk dapat salng berinteraksi secara online. Dengan adanya Schoology diharapkan siswa dapat mengunduh materi pelajaran, slide prsentasi, video tutorial, game dan lainnya yang diberikan oleh pengajar (KARTIKA MURNI, 20I6).

Dalam melakukan pembelajaran online diperlukan tambahan sebuah konten pembelajaran yang menarik, sehingga siswa tidak bosan dengan pelaksanaan belajar melalui daring. Konten yang baik dapat meningkatkan kemampuan siswa dalam memahami materi yang diberikan guru. Materi yang diaplikasikan di dalam e-learning dapat disesuaikan dengan kebutuhan guru.

\section{METODE PENGABDIAN}

Pengabdian ini akan dilaksanakan sesuai dengan tujuan dilakukan penelitian, maka metode pelaksanaan yang akan diterapkan dalam pengabdian ini adalah:

I. Observasi

Tahap ini dilakukan sebagai langkah awal dalam penyusunan proposal dan melihat masalah yang terjadi di lapangan sehingga membuat solusi yang sesuai dengan masalah tersebut. 
Pembuatan Konten Pembelajaran yang Menarik Berbasis Pemecahan Masalah di Smp bp-almunawaroh

Dian Mayasari, Sadrack Luden Pagiling

Volume 1, No. 3, Desember 2021 hal. 247-252

DOI Artikel: 10.46306/jub.v1i3.47

2. Pembuatan Konten Pembelajaran

Pada tahap ini akan dilakukan diskusi untuk menentukan konten pembelajaran serta Ims yang digunakan sehingga pembelajaran tersebut menjadi lebih menarik.

3. Paparan materi dan diskusi

Pada tahap pelaksanaannya akan dilakukan dengan metode ceramah dan diskusi meliputi penjelasan konten pembelajaran yang sesuai dengan pembelajaran yang dilakukan di dalam kelas.

4. Demosntrasi.

Pada tahap ini akan diperkenalkan pembuaatn video pembelajaran dengan menggunakan power point serta penerapannya dalam LMS berbasis pemecahan masalah, dan pada akhirnya dapat meningkatkan pemahaman siswa tentang materi yang diberikan oleh guru.

5. Latihan Terbimbing.

Latihan ini dilakukan guna melihat sejauh mana pengetahuan guru dalam membuat sebuah konten pembelajaran yang baik, serta menggunakan power point untuk membuat video pembelajaran. Selain itu, konten akan disusun oleh guru berbasis kemampuan pemecahan masalah dimana pengabdi akan memantau secara langusng proses kegiatan yang dilakukan oleh guru.

6. Evaluasi program.

Evaluasi dilaksanakan pada saat akhir kegiatan pelatihan terbimbing dimana pengabdi akan melihat kemampuan guru dalam penguasaan teknologi serta kesiapan guru dalam pembuatan konten pembelajaran yang menarik.

7. Keberlanjutan Program.

Setelah kegiatan pengabdian ini berakhir, pengabdi berencana akan melakukan kegiatan yang serupa di sekolah lain ataupun meningkatkan kualitas program yang disesuikan dengan kebutuhan dari sekolahnya.

\section{PELAKSANAAN DAN PEMBAHASAN}

Kegiatan pengabdian masyarakat dilakukan secara offline dengan guru di SMP BP AL Munawaroh.

I. Observasi.

Observasi dilakukan sebelum diadakan pelatihan. Observasi dilakukan dengan guru guru semua mata pelajaran di SMP BP AL Munawaroh. Hasil observasi yang didapat bahwa pelaksanaan pembelajaran yang dilakukan guru dimasa pandemik dilakukan secara offline dikarenakan sekolah tersebut merupakan sekolah

2. Persiapan pembuatan materi untuk pelatihan. Persiapan yang dilakuka berupa materi pwer point dan software yang akan diaplokasikanpada pembuatan konten pembelajaran. 
Pembuatan Konten Pembelajaran yang Menarik Berbasis Pemecahan Masalah di Smp bp-almunawaroh Dian Mayasari, Sadrack Luden Pagiling

Volume 1, No. 3, Desember 2021 hal. 247-252

DOI Artikel: 10.46306/jub.v1i3.47

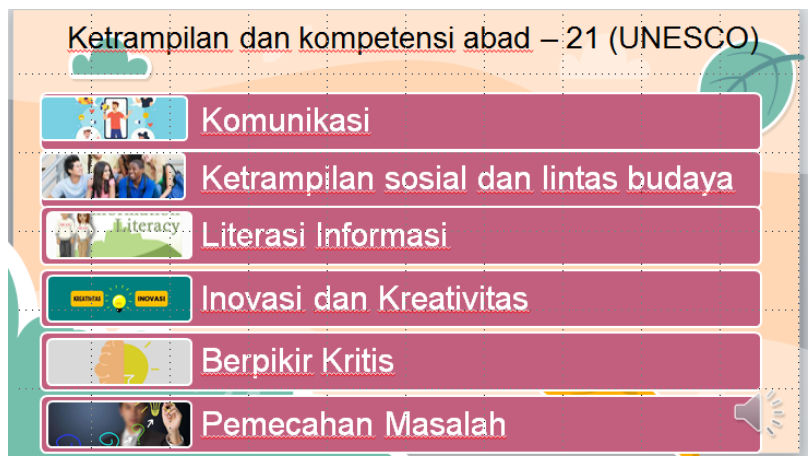

3. Paparan materi dan Diskusi

Pemaparan materi dilakukan di SMP BP AL Munawaroh dan dilakukan setelah selesai pembelajaran. Di awal kegiatan dimulai dengan memberikan arahan kepada peserta tentang konten pembelajaran yang menarik serta yang melatarbelakanginya. Pembuatan konten yang dimaksud ialah video pembelajaran yang menampilkan wajah serta suara dengan menggunakan bantuan software powerpoint yang telah dimiliki oleh peserta sekalian.

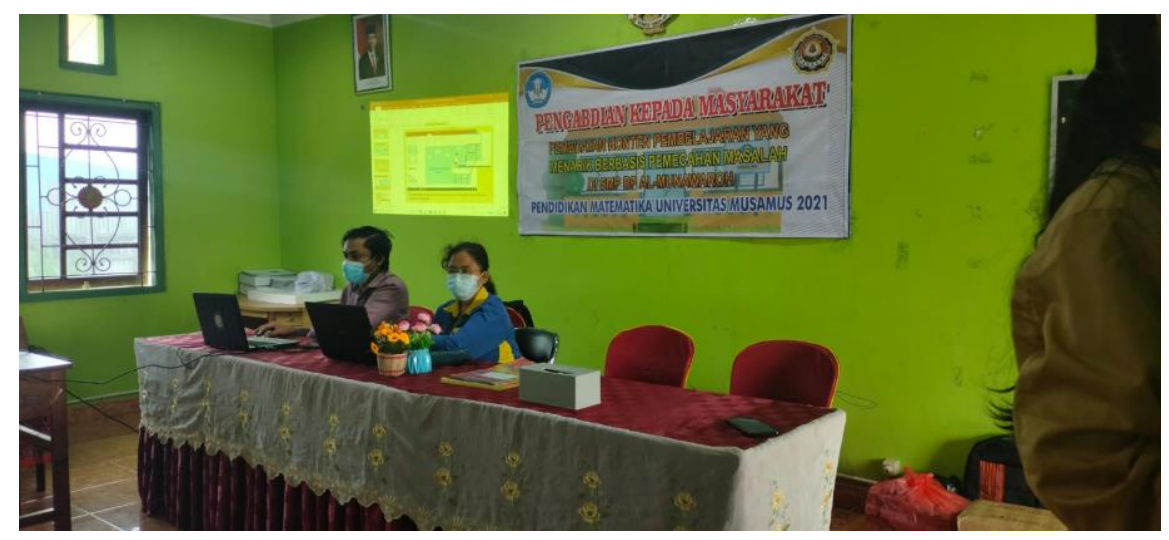

\section{Demonstrasi}

Tahapan demosntrasi yang dilakukan oleh peserta yaitu dengan mempraktekkan secara langsung pembuatan konten pembelajaran yang menarik terutama yang akan diberlakukan oleh guru disekolah.

5. Latihan Terbimbing

Setelah kegiatan pengabdian selesai, pengabdi dan tim melakukan pelatihan secara terbimbing dan terjadwal kepada guru di sekolah tersebut untuk menilai hasil kerja mereka serta memberikan pengarahan untuk pembuatan konten pembelajaran dengan tambahan aplikasi lain. 
Pembuatan Konten Pembelajaran yang Menarik Berbasis Pemecahan Masalah di Smp bp-almunawaroh

Dian Mayasari, Sadrack Luden Pagiling

Volume 1, No. 3, Desember 2021 hal. 247-252

DOI Artikel: 10.46306/jub.v1i3.47

\section{Evaluasi Program}

Program yang telah dilakukan ialah terdapat kurangnya waktu pengabdian karena menyesuaikan denga waktu sekolah yang memiliki banyak program kegiatan terutama di masa menjelang ujian semester di sekolah.

7. Keberlanjutan Program

Program ini akan berlajut untuk guru guru di luar dari SM BP AL Munawaroh terutama di daerah terpencil yang akses internetnya susah sehingga dengan menggunakan powerpoint guru dapat menjadi lebih kreativ dalam merancang pembelajarannya.

\section{KESIMPULAN DAN SARAN}

Kegiatan Pengabdian Masyarakat ini dapat menambah wawasan mengenai tips-tips saat mengajar secara daring, menambah wawasan dan pengetahuan mengenai fitur yang ada pada aplikasi powerpoint, menambah skill yang dimiliki dalam penggunaan video editing, menambah kreativitas dalam pembuatan bahan ajar dan menambah networking antar guru di Indonesia.

\section{UCAPAN TERIMA KASIH}

Terima kasih kepada Universitas Musamus khususnya LPPM yang telah mendanai penelitian ini dengan Kontrak Pengabdian Kemitraan Masyarakat Internal Universitas Musamus Tahun Anggaran 202I Nomor 167.27/UN52.8/PM/202I.

\section{DAFTAR PUSTAKA}

Batubara, H. H. (2004). Pengembangan situs e-learning dengan Moodle versi 3. I sebagai edia pembelajaran pada program studi pendidikan guur Madrasah Ibtidaiyah. I-I3.

KARTIKA MURNI, C. (2016). Pengaruh E-Learning Berbasis Schoology Terhadap Peningkatan Hasil Belajar Siswa Dalam Materi Perangkat Keras Jaringan Kelas $X$ Tkj 2 pada SMK Negeri 3 Buduran, Sidoarjo. It-Edu, I (0I), 86-90.

Munawaroh, M., Parimita, W., Parlyna, R., Susanti, S., Sumiati, A., \& Zulaihati, S. (202I). Pelatihan Pembuatan Bahan Ajar Untuk Pembelajaran Daring Menggunakan Aplikasi Video Editing Bagi Guru Dan Calon Guru. Jubaedah : Jurnal Pengabdian Dan Edukasi Sekolah (Indonesian Journal of Community Services and School Education), I (2), 190-194. https://doi.org//0.46306/jub.vli2.35

Nugraha, N. B., \& Handayani, T. (2021). PADA SISWA SMA IT SMA IT Plus Bazma Brilliant selama masa pembelajaran daring sudah menggunakan e-learning dalam kegiatan belajar mengajarnya . Sistem pembelajaran daring merupakan sistem pembelajaran tanpa tatap internet ( Oktaviani, Rini , Ulfah , \& An. Jubaedah:Jurnal Pengabdian Dan Edukasi Sekolah, I(2), I30-I36.

Pratama, R. A., \& Ismiyanti, N. (2019). Pembelajaran Matematika berbasis Edmodo Pada mata Kuliah teori Bilangan. Aksioma: Jurnal Pendidikan Matematika, 8(2), 298-309.

Rizal, S., \& Walidain, B. (2019). Pembuatan Media Pembelajaran E-Learning berbasis Moodle Pada Mata Kuliah Pengantar Aplikasi Komputer Universitas Serambi Mekkah. Angewandte Chemie International $\begin{array}{llll}\text { Edition, } & 6(\mathrm{I}), & 95 \mathrm{I} \text {-952., } & \text { I(I), }\end{array}$ http://www.nutricion.org/publicaciones/pdf/prejuicios_y_verdades_sobre_grasas.pdfhttps://www.co lesterolfamiliar.org/formacion/guia.pdf\%0Ahttps://www.colesterolfamiliar.org/wpcontent/uploads/20I5/05/guia.pdf 
Pembuatan Konten Pembelajaran yang Menarik Berbasis Pemecahan Masalah di Smp bp-almunawaroh

Dian Mayasari, Sadrack Luden Pagiling

Volume 1, No. 3, Desember 2021 hal. 247-252

DOI Artikel: 10.46306/jub.v1i3.47

Soni, Hafid, A., Hayami, R., Fatma, Y., Wenando, F. A., Amien, J. Al, Fuad, E., Unik, M., Mukhtar, H., \& Hasanuddin. (20I8). Optimalisasi Pemanfaatan Google Classroom Sebagai Media Pembelajaran Di SMK Negeri I Bangkinang. Jurnal Pengabdian Untuk Mu NegeRI, 2(I), 17-20. https://www.researchgate.net/publication/331703602\%0AOPTIMALISASI 